\title{
Public Administration and Management Reforms in CEE: Main Trajectories and Results
}

\author{
Geert Bouckaert ${ }^{1}$, Vitalis Nakrošis ${ }^{2}$, Juraj Nemec ${ }^{3}$
}

\section{Introduction}

Public administration and management reforms in Western Europe, realised during the last few years, were based on relatively common problems. Two of them seem to be crucial according to most authors. First, there was the macro-economic problem of too large a proportion of government in GDP, of significant deficits and of a perceived lack of public-sector performance contributing to GDP. A second problem was a drop of trust and legitimacy in public institutions, including politicians (Pollitt and Bouckaert 2004; Coombes and Verheijen 1997).

In CEE countries, the starting positions were quite different, and the main objective was the creation/re-creation of democratic public-administration systems. Also, country strategies were different, heavily influenced by the perspective of becoming a possible member of the EU, or not. Building democracies, organising transitions and, in some cases, preparing pre-accession were shared objectives to be realised, but methods, tools, timing and concrete targets were only shared to a certain degree.

The common feature of CEE systems is that they change drastically. Political systems change, e.g. from dictatorships to democracies, and their elites are removed. Democratic checks and balances are established. State structures are reshuffled, e.g. toward more decentralisation. The economic system changes its nature, e.g. from state monopolies to market systems with private firms. Societal and social systems with NGOs, not-for-profit organisations and citizen action groups are established and are designed for people to participate actively in the public debate and to become stakeholders of their society and their communities (Peters 1996).

1 Public Management Institute, Catholic University of Leuven, Belgium.

2 Institute of International Relations and Political Science, University of Vilnius, Lithunia.

3 Faculty of Economics, Matej Bel University, Slovakia. 
To achieve planned changes, CEE countries had to choose their strategies. In focusing on the administration and the management of public systems, five scopes of reform are possible, from very narrow and limited to a very widespread and broad span of reform (Pollitt and Bouckaert 2004). Choosing one of these models has tremendous practical implications for the content of a reform programme, for the choice of the reform projects, for the sequence and timing of the reform portfolio. It also requires different tactical choices to be made. One of the issues is how many degrees of freedom there are to reform the public sector.

Just as in many other countries, mixed strategies have been chosen for public-sector reform in CEE countries, and these choices have changed over time. However, it seems that the span of reform has rather been broad than narrow. It also seems that tactics could have been more visible than strategy because of electoral cycles.

This brings us to the question of the trajectories to move ahead. Our article, heavily based in the joint NISPAcee research project ${ }^{4}$ tries to respond to some selected dimensions of the question of what the common and different trajectories and selected outcomes of public administration/management reforms are in the CEE region.

\section{Reform trajectories: Commonalities and differences}

Public-administration and management reforms in CEE are not realised as one uniform process, neither regarding their contents, nor their timeframes. In this part of our paper, we discuss patterns of reform trajectories.

\section{Reform start and phases}

All available information about reforming public administration in CEE indicates that the national patterns partly differ regarding the beginning and content of reforms, depending on local political, social and other environments. Two subgroups are fully visible:

a) Countries in Central Europe, including the Baltic States

b) Countries of the former Soviet Union (NIS region)

In Central Europe, the first democratisation phase, focusing on building new public-administration systems, which started in early 1990, is relatively similar in phasing and reform contents. It focused on replacing of old "socialist" structures

4 Network of Schools and Institutions of Administration in Central and Eastern Europe. The results of this research project were published in 2009 in the form of a book (Public Management Reforms in CEE). 
with new democratic ones, for example the establishment of a real local self-government system, democratic elections, etc.

The second common aspect for this region is the EU pre-accession phase at the end of the nineties and the beginning of the $21^{\text {st }}$ century (Romania was slightly later). Despite the fact that the public-administration system was not an explicit part of the Acquis Communautaire, several targets were set by the EU regarding administrative/management reforms in the public sector. Typical common tasks were: establishing the Civil Service; further decentralisation, especially creating regional self-governments; introducing e-government services and improving the system of financial controls in order to be able to utilise EU funds.

The "pre-accession" wave of reforms has many similarities, but also some content and time differences (the Civil Service system was established, for example, in Estonia in 1996, but in Slovakia, it only came in 2001). Comprehensive reform packages were introduced in several countries at more or less the same time. The Estonian Government introduced a "Concept for Public Administration Development", adopted in 1999. The Czech Republic document "Concept of public administration reform" from 1999 included a complex reform package divided into two parts - (1) reform of regional public administration and (2) modernisation of the central state administration. After the general elections of 1998, the new Slovak government established the position of Government Appointee for Public Administration Reform and the main reform document, focusing especially on decentralisation, the "Strategy of decentralisation and public service reform", which was published in 1999. The new separate regional development framework was introduced in 2000 in Lithuania. Latvia adopted the document "Public Administration Reform Strategy 2001-2006" and its implementation plan as its main reform policy. Similar reform activities were happening at the same time in Hungary, Lithuania, Poland, and in Romania with a delay of 2-3 years (due to a later start of the accession process).

The situation in other CEE countries cannot be reduced to one uniform pattern. The contents and timing of reforms is individual and depends on the country-specific internal and external environment. The limited local stability in Kyrgyzstan meant that basic administrative reforms in the country were initiated only in 2001. For the first time, Public Management Reforms as a government priority were articulated in the Comprehensive Development Framework up to 2010 (2001) and then reflected in the National Poverty Reduction Strategy (NPRS) (2003). Apart from those two strategic documents, the Public Management Strategy was developed in 2003, focusing on the basic mechanisms needed for the creation of a system of public administration. In Ukraine, some changes already began in the period 1991-1997, characterised by the chaotic reform of both the socio-economic sphere and the state machinery. Several decrees and regulations were prepared later on, but the increasing political instability limited 
their success or even their chance to be implemented. In Kazakhstan, the main aims of the public-sector reform agenda were set within a long-term vision for Kazakhstan, announced by the President in 1997, and called "Kazakhstan 2030". Reform strategies comprised several main goals, such as increasing the effectiveness of the government, implementing modern information technology, eliminating bureaucracy in government bodies and restricting state interventions in the economy. Compared to other countries, thanks to their relative political stability and wealth, some planned targets were also achieved. In Armenia, the reform efforts might be characterised by their long interruptions and sporadic nature. The first attempts at a legal framework for the civil service were articulated in 1994 - the concept of the Civil Service was re-developed by the Government in 1997 - but its implementation was again delayed in the light of the 1998 change in power. The final version of the Civil Service Law was enacted only in December 2001. Under such conditions during the first reform stage (1999-2003), only basic systems for managing the core government apparatus were established. The second reform stage (2003-2008) focuses on improving broader public services and still lacks complexity and comprehensiveness.

The specific case is Russia. According to Obolonskij (2009, 259-322), there were several attempts to reform Russia's public administration and civil-service system. The first started as early as 1991, when the Civil Service Office (Glavnoe upravlenije po podgotovke kadrov) was established by the Presidential Decree and was also supported by French experts. This Office was abolished in late 1994; because of too limited success (combination of the influence of "old" cadres and French advice did not deliver much). The second phase is connected with the period 1997-1999, when President Jeltzin established the Committee for administrative reforms, which formulated the reform strategy. However, this document was never implemented because of major political changes. In the period 1999-2002, especially in its beginning, the public-administration reform was discussed and analysed many times, but only in 2002, some concrete steps happened. President Putin first presented the need for radical reform in the Parliament, and in November 2002, he approved the document "Federal Programme of the Civil Service Reform 2003-2005". In spite of some implementation delays, the Civil Service Law was accepted by the Parliament in 2004, the Civil Service Office established in 2007 and most of the planned Presidential decrees were adopted. However, the real impact of these changes may only become visible in the future.

A simplified picture of what happened, and when, based on the cluster-analysis method is provided in Table 1. 
Table 1

Country clusters: Reform contents and timing

\begin{tabular}{|l|l|l|}
\hline Cluster & Main features & $\begin{array}{l}\text { Examples of } \\
\text { countries }\end{array}$ \\
\hline 1 & $\begin{array}{l}\text { First PA/PM reforms began in the early nineties and in the } \\
\text { beginning, reforms were supported by many international } \\
\text { donors to supplement limited local experience. From the } \\
\text { mid-nineties on, the dominant goal was EU accession and } \\
\text { the necessary administrative adjustments. After 2004, } \\
\text { the speed of the reform more or less slowed down. }\end{array}$ & $\begin{array}{l}\text { Czech Republic, } \\
\text { Estonia, Hungary, } \\
\text { Latvia, Lithuania, } \\
\text { Poland, Slovakia, } \\
\text { Slovenia }\end{array}$ \\
\hline 2 & Similar to 1, but with a delay of a few years. & Romania, Bulgaria \\
\hline 3 & $\begin{array}{l}\text { A stable and strong presidential system allows for } \\
\text { relatively successful changes, especially after 2000. }\end{array}$ & Kazakhstan \\
\hline 4 & $\begin{array}{l}\text { The reform was systematically blocked or at least slowed } \\
\text { down by "old cadres". Necessary legislation was adopted } \\
\text { only recently, its impact cannot be assessed yet. }\end{array}$ & Russia \\
\hline 5 & $\begin{array}{l}\text { Too much local instability still harms the needed reforms } \\
\text { today. }\end{array}$ & $\begin{array}{l}\text { Armenia, } \\
\text { Kyrgyzstan, Ukraine }\end{array}$ \\
\hline
\end{tabular}

Source: authors

\section{Reform reasons and driving forces}

Similar to the phasing and main contents, the purpose of the reforms and their driving forces are relatively similar in Central Europe, but in this case, we also find some important similarities in Eastern European states.

The first reform phase in Central Europe, at the beginning of the nineties, represented a clear attempt for democratisation, including the democratisation of public administration, fulfilling the need to establish standard administrative structures, which function in developed countries. This phase was dominantly supported, and also supervised, by SIGMA OECD experts and financed by the PHARE programme. Other international donors were also very active during this period, such as the World Bank, the International Monetary Fund and country specific "donors" - for example, Estonian public-management reform practices have been influenced by relevant solutions in Germany (the legal framework, in particular), the UK and the Nordic countries (individual management tools). Such help was necessary because of the shortage of human and financial resources, the lack of experience and the urgency for solutions.

However, compared to Eastern Europe (see below), the major decisions about the design and operation of public-administration systems in Central Europe have remained very much "home-grown", also thanks to the effective reform coordination activities of SIGMA, OECD. Whereas policy transfer was an important policy 
tool in the 1990s, this has been gradually replaced by a more knowledgeable process of policy-learning in recent years.

As already described above, the second phase of reforming public-administration systems in Central Europe is very closely linked to the EU accession process. The role of other international organisations diminished, and only a few, dominantly sectoral or very specialised activities (e.g. the establishment of a cost-centre system in the Slovak public administration supported by German funds) were still supported by bodies such as the World Bank, the International Monetary Fund and country-specific partners.

The EU financially supported the reinforcement of institutional and administrative capacities under its PHARE programme and Transition Facility and, later, by structural allocations. The impact of the EU accession process on Central European public-administration/management reforms is obvious, important, but also limited. As the Acquis Communautaire did not include specific comprehensive chapters providing benchmarks for national reforms, and EU evaluations focused mainly on partial elements of administrative systems (establishment of the Civil Service, financial control, etc.), internal motivation for administrative reform remained the dominant factor of the reform contents. Thus, accession to the EU may have sped up certain developments, but it did not provide complex structurally innovative solutions.

After the accession, the EU pressure for changes almost disappeared, and reforming public administration became a more "voluntary" and nationally motivated process. The reaction to such new conditions was relatively different between new EU member states. Some of them continued to try to realise more complex reform plans (Latvia, Lithuania) and others significantly slowed down, and instead of the required complex reforms, only a few small changes occurred (Slovakia, Czechia). One of the reasons for such a particularity might be the fact that EU structural-fund allocations for 2007-2013 were made only for the purpose of improved administrative capacity and public-administration efficiency; thus complex reform measures were difficult to finance from external resources.

A simplified picture of the principal reform reasons and driving forces in Central Europe, based on the cluster-analysis method, is provided in Table 2.

The situation in most areas of Eastern Europe (Russia may be an important exception) shows that the majority of reform changes in this region were driven by international donor agencies. Compared to Central Europe, where local reform capacities were created step by step, and most funds were provided by the EU in a relatively coordinated form, in this region, little progress would be possible without external help. Many positive changes would not be possible without the use of international expertise and funds, as local capacities and financial resources were, and still are, very limited. 
Table 2

Central Europe country clusters: Reforms, reasons and driving forces

\begin{tabular}{|l|l|l|}
\hline Cluster & \multicolumn{1}{|c|}{ Main features } & \multicolumn{1}{|c|}{ Countries } \\
\hline 1 & $\begin{array}{l}\text { First PA/PM reforms represented the need for democratisation, } \\
\text { a switch from the old system and a demonstration of the will } \\
\text { to change. From the mid-nineties on, the most important } \\
\text { reason and driving force for reform was EU accession. After the } \\
\text { accession, there were few initiatives. }\end{array}$ & $\begin{array}{l}\text { Czech } \\
\text { Republic, } \\
\text { Poland, } \\
\text { Slovakia }\end{array}$ \\
\hline 2 & $\begin{array}{l}\text { First PA/PM reforms represented the need for democratisation, } \\
\text { a switch from the old system and a demonstration of the will } \\
\text { to change. From the mid-nineties on, the most important } \\
\text { reason and driving force for reform was EU accession. After the } \\
\text { accession, reforms continue. }\end{array}$ & $\begin{array}{l}\text { Latvia, } \\
\text { Lithuania, } \\
\text { Hungary }\end{array}$ \\
\hline 3 & $\begin{array}{l}\text { First PA/PM reforms represented the need for democratisation, } \\
\text { a switch from the old system and a demonstration of the will to } \\
\text { change. From the mid-nineties on, the most important reason } \\
\text { and driving force for reform was EU accession, but many or } \\
\text { most changes would happen without EU pressure. After the } \\
\text { accession, reforms continue, but to a limited degree. }\end{array}$ & Estonia \\
\hline 4 & $\begin{array}{l}\text { Reforms began mainly in relation to EU accession and are still } \\
\text { connected to it. }\end{array}$ & Romania \\
\hline
\end{tabular}

Source: authors

However, several evaluations of foreign help highlight several negative features. For example, frequently there are too many donor agencies crowding an individual ministry. In such a situation, the application of "best global practice" is almost meaningless. Moreover, most projects are built upon the "client's needs" identified for the government by external "experts", rather than responding to the needs and demands of the present day.

Shakarashvili $(2005,13-14)$ adds to this:

Especially at the early phases of the post-Soviet reforms, these countries were strongly attracted by the idea of "westernisation" and were open to close collaboration with international (predominantly Western funded and Western influenced) organisations. Often, this collaboration resembled a teacher-pupil type of relationship, when governments would not object to following the recommendations of external partners without questioning their validity or appropriateness for the local context, whilst the Western agencies were not shy to reveal the 'consultant knows it all' attitude. The policy design recommendations were often based on the specific experience and knowledge of international experts in their own countries.

These problems are real and harmful. However, what would have happened without foreign help? Would countries have managed to reform their governance 
systems better without external pressures and help - or would almost nothing happen? Foreign help is still necessary in most countries in Eastern Europe; however, if such a chance exists, more effective, more customised and coordinated approaches may deliver more, with less resources and pain.

\section{Reform types}

As already indicated at their beginning after 1989, or later in the CIS region, all reforms focused mainly on the establishment/re-establishment of basic democratic administrative values and structures. This period was also very much connected to capacity building, where the still necessary basic administrative changes were mixed with several public-management elements. The analysis of the Hungarian reform packages clearly indicates this situation, distinguishing between "classic" publicmanagement reform measures and "CEE specific measures", such as fine-tuning or legal-structural retrenchment of existing institutions, improving the bureaucratic workflow and control in administrative organisations, or measures to achieve EU conformity of certain institutions or policies. When comparing the relative proportion of these two classes, one may conclude that the share of public-managementtype measures within the overall set of reform measures was very low at the beginning, but has been constantly rising significantly.

The Hungarian reform also identifies one important and almost common feature of reforming administrative systems, at least in Central Europe: the tradition of the "Rechtsstaat" culture characterised, in general, by the dominant role of law and legalism in the way the government thinks and acts. This culture significantly influenced the contents of many reform measures, when governments tried to treat problems by legal norms and not best practices. Pavel (2009) showed this fact when evaluating the development of the public-procurement law in the Czech Republic. Both the number of paragraphs and the number of pages increased with every new amendment of this law, independent of the fact that a value for money audit of public procurement is much more important, compared to the probity aspects of the process. Legislators tried to improve the quality of procurement by extra legal measures, but without any real impact on efficiency, effectiveness and economy. The Czech report also provides the evidence for this issue: "One of the answers to the question 'What is the goal of the reorganisation?' was: 'The goal of the reorganisation is to reorganise"' Also, the Romanian report signalled "over-legalisation": both civil servants and citizens almost completely agree with the fact that the Romanian legal framework is too complicated.

The relationship between classic administrative changes and public-management changes, which changed over time, was also very different between the selected countries. To describe the situation we can use the Coombes and Verheijen 
(1997) and Pollitt and Bouckaert (2004) classifications of reforms - these two classifications have the same base and can be simplified as follows:

1. Radical public-management type of reform;

2. Mixed type of reform;

3. Incremental reform.

If we exclude Eastern European countries, where reforms are still in their early phase and it would be very difficult and preliminary to try to label them, the situation in the remainder of the countries seems to be as outlined in Table 3.

\section{Radical NPM approach or "Weberian" administration?}

Estonia is the best example of a CEE country where NPM ideas have prevailed in various public-administration reform concepts and strategies originating in the second half of the 1990s, and a certain over-idealisation of the private sector (and free market) still prevails today. Massive privatisations have led to the selling-off of strategic enterprises such as the railways (in 2001, until its re-nationalisation in 2007) or crucial services such as emergency medical aid without much public discourse or market-testing. Because of this, Estonia also frequently serves as the benchmark for evaluating the appropriateness and suitability of NPM principles and tools for the transitional countries. Most authors are not very optimistic in this direction, for example:

"In Central and Eastern European (CEE) transition countries ... public administration has had to face special challenges because both the creation of a political democracy and the implementation of the principles of efficiency and effectiveness have become crucial tasks of modernisation at the same time" (Jenei and Szalai 2002, 368).

"NPM is particularly bad if pushed upon transition and developing countries because if it can make any sense, then it is only in an environment of a well-functioning democratic administrative tradition" (Drechsler 2005, 101).

"The greater the shortcomings in a country's established management practices, the less suitable the [NPM] reforms" (Schick 1998, 124).

"Once a so-called Weberian administrative system is institutionalised, then it may make sense to consider how best to move from that system towards a more 'modern' system of PA" (Peters 2001, 176).

All the quotations above and other experience indicate that NPM as a reform ideology may not be the proper approach for reforms in transition countries, but many NPM-based policies and instruments should be implemented as soon as possible. For example, performance evaluation methods, especially benchmarking, may really help to improve transparency and accountability. 
Table 3

Classification of reforms in Central Europe

\begin{tabular}{|c|c|}
\hline Country & Reform type \\
\hline $\begin{array}{l}\text { Czech } \\
\text { Republic }\end{array}$ & $\begin{array}{l}\text { Dominantly incremental and legalistic reforms during the entire evaluated period. } \\
\text { Few management reforms after } 2000 \text {. The "Conception of public administration } \\
\text { reform" from } 1999 \text {, planned for complex changes, but only administrative measures } \\
\text { were really implemented. New liberal government elected in } 2006 \text { tried to propose } \\
\text { NPM changes, but had no real power to implement them. }\end{array}$ \\
\hline Estonia & $\begin{array}{l}\text { Estonian reforms seem to be the most radical and NPM-based. One of the main } \\
\text { challenges in Estonia has been posed by the desire to jump straight into having } \\
\text { modern management systems without previously establishing a solid base - the } \\
\text { classical hierarchically structured public administration. The central aim in Estonian } \\
\text { public administration has not been to build a solid ground for democracy, but to } \\
\text { improve the efficiency of public institutions. Yet, as a consequence of the policies } \\
\text { adopted by successive neo-liberal governments, the underlying theme behind } \\
\text { government-reform initiatives has been reducing the role of the state. Such an anti- } \\
\text { state attitude has contributed to the development of ideas based on the minimal } \\
\text { state. }\end{array}$ \\
\hline Hungary & $\begin{array}{l}\text { Hungarian reforms can be characterised as the mixed model, starting from a } \\
\text { dominantly incremental and legalistic reform approach at the beginning of the } \\
\text { nineties, slowly changing to a mixed type with a radical NPM switch in the post-2006 } \\
\text { period. Current NPM changes focus on two central elements - downsizing (including } \\
\text { a radical decrease in civil-service employment - at the territorial and local levels, this } \\
\text { was well into the two-digit range, in some cases possibly even achieving } 30 \text { to } 50 \text { per } \\
\text { cent) and radical reforms of the human resource management system. }\end{array}$ \\
\hline Latvia & $\begin{array}{l}\text { Latvian reforms can also be characterised as the mixed model from the beginning to } \\
\text { the current reform activities. Several NPM types of reform changes were implemented, } \\
\text { especially in the later phases of reforming the public-administration system, but NPM } \\
\text { never dominated the reform strategies. }\end{array}$ \\
\hline Lithuania & $\begin{array}{l}\text { The country report suggests that Lithuania appears to reach a second category } \\
\text { (mixed model) of states called "modernisers" according to the classification by Pollitt } \\
\text { and Bouckaert (2000). In the pre-accession period, Lithuanian public-management } \\
\text { reform was characterised by ad-hoc and sectoral efforts. From about } 1996 \text { to 2004, } \\
\text { public management reforms became driven primarily by Lithuania's accession to } \\
\text { the EU. More intensive competition over NPM-type reforms began only in the post- } \\
\text { accession period. }\end{array}$ \\
\hline Poland & $\begin{array}{l}\text { Poland is a typical representative of a prevailing legalistic approach to reforms and } \\
\text { can be placed in the third group of reform countries (incremental changes). Poland is } \\
\text { continuously reorganising its management systems in the public sector. New Public } \\
\text { Management had a limited impact on the Polish administration by providing ideas } \\
\text { and demands for recognising the need to modernise the Polish administration and, at } \\
\text { the same time, to reduce its size. }\end{array}$ \\
\hline Slovakia & $\begin{array}{l}\text { Slovakia, from the point of view of the whole investigated period, represents a mixed } \\
\text { ("modernisers") approach, but deeper analysis distinguishes three main phases. Prior } \\
\text { to } 2003 \text {, the reform was dominantly incremental and legalistic, with few NPM ideas } \\
\text { realised. During the second election period of the liberal Prime Minister Dzurinda's } \\
\text { government ( } 2003-2006 \text { ) radical NPM changes were realised, such as massive } \\
\text { decentralisation and the introduction of performance-financing schemes. The new } \\
\text { Prime Minister Fico's coalition, in power from } 2006 \text {, returned to the idea of a powerful } \\
\text { state dominating in the system of the delivery of public functions. }\end{array}$ \\
\hline Romania & $\begin{array}{l}\text { The information from the country report suggests that Romania lies somewhere } \\
\text { between group two and three. Each government, after the } 1989 \text { revolution, has } \\
\text { the reform of public administration on its agenda. Though the concept of public } \\
\text { management has not always intertwined with the reform of public administration, } \\
\text { some new managerial ideas such as the use of contractualisation, strategic } \\
\text { management and planning, performance-measurement systems, reform networks, } \\
\text { etc. were included in reform packages. }\end{array}$ \\
\hline
\end{tabular}

Source: authors 
To take the full complexity into account, we also need to stress that NPM is one extreme, but a dominantly legalistic approach to the reform is the second (and also ineffective) extreme. Over-legalisation and over-regulation normally do not deliver efficiency, economy and effectiveness, as we already indicated in the example of public-procurement law. Under conditions of limited respect for the law, typical of most transition countries, we attempt to improve the performance of public administration by extra laws, norms and regulations which cannot work but simply create an extra burden for business and the citizen.

The conclusions are straightforward. Neither radical NPM nor simple legalism is the best option for public-administration reforms in transition countries. Some effective balance, customised for local conditions, should be suggested. In any case, the implementation of radical NPM reforms might become meaningful if the basic and reliable "Weberian" administration is not well established.

To what extent such a recommendation might really be implemented is unclear - the reality of political processes in this group of countries does not provide much space for effective policy-making and policy implementation (Dunn, Staronova and Pushkarev 2006). Short-term pure political decisions dominate; long-term policies are the exception.

\section{Reform outcomes: Still much to do...}

Public-administration and management reforms in the CEE region can be evaluated from many different angles, but it is necessary to accept that they delivered many important and necessary positive changes and improvements, compared to the situation at the beginning. In many cases and areas, effective practices were established, and the gap between the quality of administration in developed countries and in the region is becoming smaller and smaller. In the next section of the text, we highlight the most important developments in crucial public-management "sectors".

\section{Financial management}

From a macroeconomic point of view, it is necessary to admit that all EU member countries significantly improved their financial discipline, in part thanks to the implementation of modern budgeting methods. Until the financial crisis at the end of 2008, very few countries had to cope with excessive deficits and large debt levels, beyond the Maastricht criteria (Hungary, Poland). Slovenia and Slovakia managed to join the Euro zone.

However, since the start of the financial crisis, the financial health of most $\mathrm{CEE}$ and former Soviet Union states has deteriorated markedly, reflecting the ongoing crisis as well as the packages of economic stimuli adopted in several countries. 
Latvia, Hungary, Romania, Serbia, Belarus and Ukraine found it necessary to approach the International Monetary Fund for financial assistance.

Slovak (macro) public-financial-management reforms are (probably together with the Baltic States) the most progressive and radical. From 2005 on, Slovakia began with a full-accrual medium-term programme and performance budgeting at the national level, and from 2010 on, this method will also be applied at the municipal level. A switch to programme-performance budgeting is an ongoing process in the region, with its first steps being taken in the East (e.g. in Armenia or Kazakhstan). Such process is crucial because it helps link inputs to outputs, outcomes and results, and, if properly implemented (or with some time delay), it can significantly increase the "value for money" from public expenditure.

Several other public-financial-management tools began to be routinely used, especially in Central Europe - such as contracting, outsourcing, public procurement or even public-private-partnerships projects. As the Slovak report indicates, their results in delivering value for money are significantly different and depend on concrete local conditions and the environment. High levels of corruption are one important barrier to success. Cost-benefit analysis and impact analysis are more and more commonly practised, partially because of the requirements of the EU structural funds.

A relatively weak point is the efficiency of financial controls and auditing in $\mathrm{CEE}$. As the Slovak report suggests, the probity - compliance - legalistic approaches dominate, and auditing value for money is still a limited practice. From all trajectories of financial-management reform (budget, accounting, audit), Lithuania made good progress in the area of financial and performance audit: it enriched financial and compliance audits with some performance audits carried out by the National Audit Office.

Decentralisation and fiscal decentralisation is a particularly common feature in the language of public-management reforms in the CEE region. However, its scale and reality differ significantly. The most radical changes of decentralisation can be found in Estonia and Slovakia. After 2000, decentralisation was the main motto of reforms in Slovakia. The opposite can be found in the East. For instance, Ukraine has not yet created "real" self-governments. In many, especially "Eastern" cases, decentralisation, and fiscal decentralisation, occurred mainly de jure, and not often de facto.

The most important changes of formal decentralisation are connected with the creation of regional and local self-governments and the transfer of competencies and resources to these levels. The impact of these changes is mixed, reflecting the opportunities and limitations of decentralisation as a reform tool as well as the need to tailor decentralisation to a particular reform environment. An improper allocation of responsibilities limits the chance for economics of scale and increases transaction costs. Too small government units suffer from a lack of competence 
and financial resources. Therefore, "the administrative capacity of sub-national governments and the administrative and compliance costs of decentralisation must be taken into account when assigning expenditure among levels of government" (Allen and Tommasi 2001, 74).

All countries examined expressed (more or less "loudly" and concretely) the will to decrease the overall civil/public-service/public-sector size, Estonia being the most radical in this area. However, Estonia no longer has the smallest government in CEE (measured by government expenditure as a percentage of GDP): Slovakia's government expenditure dropped by 19 per cent in the period 2000-2008 (see Table 4 below). This table also points to different dynamics in overall public costs of production (covering the compensation of employees and intermediate consumption in the public sector): these costs decreased in five CEE states (Estonia, Lithuania, Poland, Slovenia and especially Slovakia), but increased in four other CEE countries (Bulgaria, Latvia, Hungary and Romania) over the period 1996-2008.

In addition, most planned "reduction" targets were not achieved, partly because EU membership required the recruitment of new civil servants to deal with EU matters. Czechia, Poland, Slovakia and others formally declared a strategy of deployment several times. However, the total size of public employment (in number of persons) has stabilised or is even growing everywhere (relative figures are influenced by the fast economic growth).

"Downsizing" is also connected with privatisation, contracting and outsourcing and the creation of a real "public-private-civil sector mix". The scale of such processes differs, with Estonia again being the most radical case. In this area, one should stress that most countries still overestimate - or even politicise - the ownership principle in the processes of the production of public services. Changes in governments are connected with a switch of attitudes ("left"-wing governments prefer public alternatives, liberal governments private solutions) - and as a consequence, reversed and costly organisational changes happen. The classic example is health care (Nemec and Lawson 2008) - at the same time Slovakia is reconsidering its pluralistic health-insurance system, and Poland is starting to work on its implementation (in both cases, the costs of change will be higher than any possible benefits). At the same time when Slovakia revises its liberal health-care reform, Czechia starts to implement it.

In less developed countries, downsizing is also a necessary reaction to a lack of public resources, caused by weak economic performance. With a lack of resources, privatisation does not help but simply limits the chance of many citizens to have the necessary access to core services, especially health care (Armenia). 


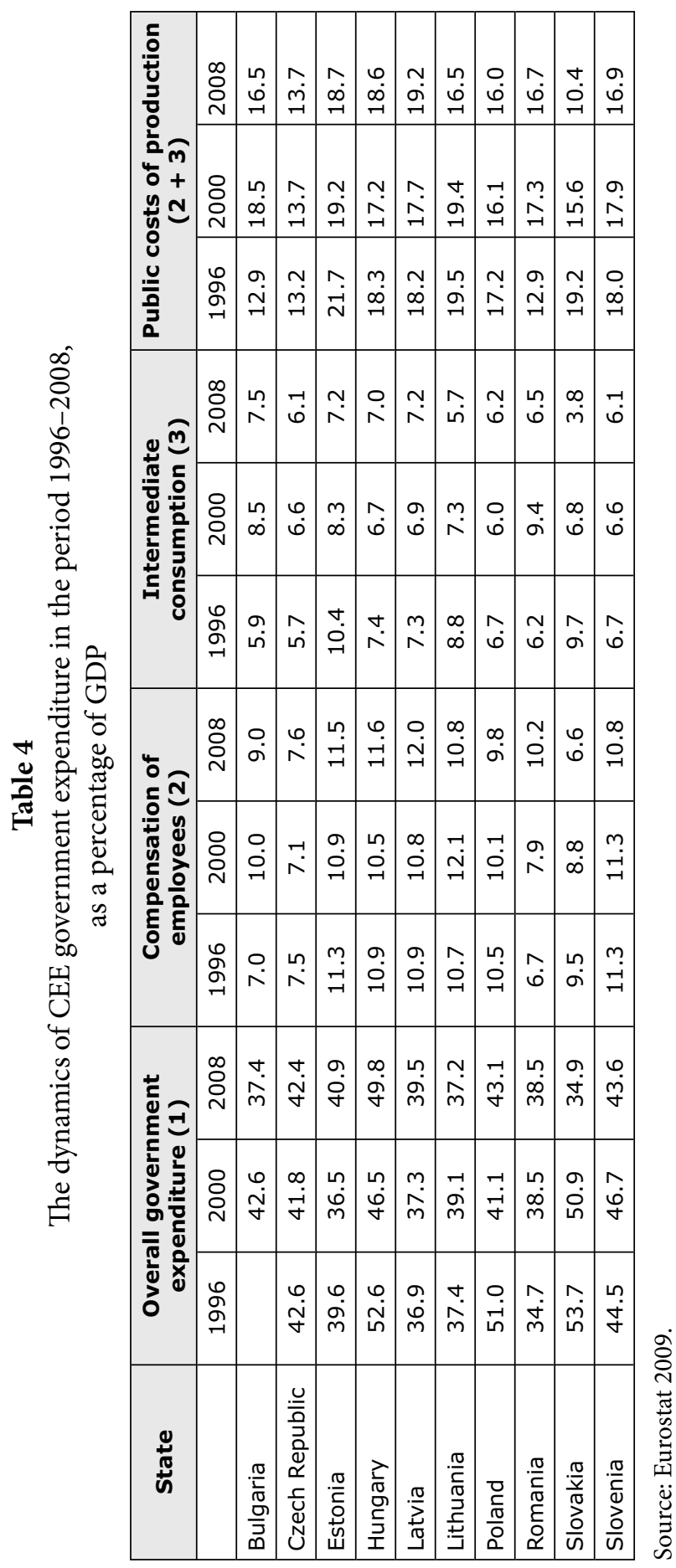




\section{Civil service and human-resource management}

The recent comparative study of the civil-service systems in CEE states found significant variation in the progress of civil-service reforms and their sustainability after EU membership (Meyer-Sahling 2009). It was possible to distinguish three groups of countries, varying in terms of the current fit with European standards of administration and in terms of the professionalisation trajectory (see Table 5 below).

Table 5

Fit with European principles: Comparison across countries

\begin{tabular}{|l|l|l|l|l|l|}
\hline $\begin{array}{c}\text { Current Fit } \\
\text { \& } \\
\text { Post-accession } \\
\text { pathways }\end{array}$ & High fit & $\begin{array}{l}\text { Medium to } \\
\text { high fit }\end{array}$ & Medium fit & $\begin{array}{l}\text { Medium to } \\
\text { low fit }\end{array}$ & Low fit \\
\hline $\begin{array}{l}\text { Constructive } \\
\text { continuation of } \\
\text { reform }\end{array}$ & Lithuania & $\begin{array}{l}\text { Latvia } \\
\text { Estonia }\end{array}$ & & $\begin{array}{l}\text { Hungary } \\
\text { Slovenia }\end{array}$ & \\
\hline $\begin{array}{l}\text { Constructive } \\
\text { reform reversal }\end{array}$ & & & $\begin{array}{l}\text { Slovakia } \\
\text { Poland }\end{array}$ & $\begin{array}{l}\text { Czech } \\
\text { Republic }\end{array}$ \\
\hline $\begin{array}{l}\text { Destructive } \\
\text { reform reversal }\end{array}$ & & & &
\end{tabular}

Source: Meyer-Sahling 2009.

On the one hand, the fit with European principles was found to be the highest in the three Baltic states (Lithuania, Latvia and Estonia), which constructively continued their civil service reforms (Meyer-Sahling 2009, 71). On the other hand, Slovakia, Poland and the Czech Republic share their relatively low fit with European principles of administration; they are the mases of destructive reform reversals (Meyer-Sahling 2009, 72).

According to the qualitative comparative analysis, low politicisation of the civil service in the Baltic states (compared to other new EU member states that joined the EU in 2004) explains the good ratings of their civil service in the 2009 SIGMA report. However, the good achievements of the Baltic states do not mean that their civil-service systems have become consolidated. Although until recently, Lithuania's civil-service reforms were marked by relative continuity and consistency, a new coalition government started politicising the higher civil service. This illustrates the vulnerability of the civil-service professionalisation even in more advanced states of CEE.

All the countries examined established some type of civil-service system; only the characteristics and timing are different, with Hungary being the first country to adopt a modern civil-service law in 1992. However, the SIGMA report shows that early achievements have not been sustained: from being the regional leader, Hunga- 
ry turned into an average performer. It was recognised in the SIGMA report that the Hungarian case represents the greatest contradiction in the region (Meyer-Sahling $2009,73)$. The Hungarian case revealed that in the absence of classical bureaucratic characteristics and in the presence of high politicisation, the willingness to experiment with modern NPM techniques has not produced the desired outcomes in the civil-service area.

Outside the new EU member states, progress in the civil service area has been even more limited. In the absence of the effective conditionality of EU membership, the civil-service reforms of the former Soviet republics (except the Baltic states) have been driven by the international donors and domestic political forces. Despite some efforts to modernise the civil-service systems, the professionalism of the public administration remains rather low and with frequent incidents of administrative corruption (with these countries at the bottom of the 2008 corruption-perception index). A weak democratic state, stemming from the ability of the post-communist political-administrative regime to retain its power, was found to be one of the main reasons for failed public-management reforms in this region.

\section{Performance and quality management}

Many CEE states introduced certain performance-management schemes. In the World Bank's report, together with Latvia, Lithuania has received the highest rating of performance management in Central and Eastern Europe (around level three), with "a planned, implemented and reviewed (in both cases) performance management system in place, even if not yet fully functional across all elements of the system" (World Bank 2006, 20). Other states of CEE (Hungary, the Czech Republic, Slovenia, Estonia and Poland) were not rated higher than level 1: although their performance-based approached have been planned, they remained unimplemented. The design of certain political initiatives and their implementation (often influenced by the conditions of financial crises) largely explains cross-national variations in the performance-management area.

However, no CEE state has developed a fully-fledged performance-management approach comparable to the most advanced systems of performance management found in the US, the UK, Canada or Australia (Bouckaert and Halligan 2008). Also, the development of a modern performance-management systems does not automatically imply an improvement in the efficiency of public spending or the quality of public services. The in-depth assessment of the Lithuanian performancemanagement system found that the quality of performance information is poor and its use in the decision-making process is limited apart from external reporting (Nakrošis 2008, 92). According to the World Bank, (based on the assessment of the Slovak Republic, Romania and the Kyrgyz Republic) "instituting performance management in environments where the foundations of public administration have 
not been established may be inconsequential, at best, or risky at worst in transition countries" (World Bank 2003, ix). A merit-based civil-service system and a wellfunctioning system of administrative procedures are the most important elements of these foundations.

Quality initiatives are frequent, but usually decentralised in the CEE region. Many public bodies decided to implement ISO or other quality-management systems (such as standards for public services, one-stop shops, citizens' charters, an independent ombudsman, Common Assessment Framework) to improve the quality of internal processes and outputs. Also, CEE states vary significantly in terms of the scope of certain quality-management initiatives (see Table 6 below with regard to the number of registered users of the CAF).

Table 6

The number of registered users of the Common Assessment Framework in the new EU member states

\begin{tabular}{|l|c|}
\hline \multicolumn{1}{|c|}{ Country } & Number of registered users of the CAF \\
\hline Bulgaria & 5 \\
\hline Czech Republic & 58 \\
\hline Estonia & 18 \\
\hline Hungary & 118 \\
\hline Latvia & 5 \\
\hline Lithuania & 9 \\
\hline Poland & 53 \\
\hline Romania & 33 \\
\hline Slovakia & 18 \\
\hline Slovenia & 50 \\
\hline
\end{tabular}

Source: www.eipa.nl

However, as some quality comparative activities indicate (e.g. the European Public Service Award), CEE countries still need to improve significantly and cope with the more intensive demand from citizens for quality public services, which will certainly increase with time.

\section{Public trust in governments and macro-economic problems in CEE states}

Public trust in government was one of the most important reform objectives in Western Europe (Bouckaert 2009). According to the recent Eurobarometer report, public trust in government in CEE states is below the EU 27 average in all states of Eastern European tradition, except Slovakia (where it is close to the EU 27 aver- 
age). It is interesting that trust in government is well above the EU 27 average in all Nordic states, including Estonia (62 per cent compared to the average of 34 per cent), which was assigned to the Nordic tradition in some public-administration literature. The fact that the public has a low level of trust in CEE governments shows that public management reforms have not generated positive effects. Nevertheless, public trust in government still remains a challenge in Western European states, although they started from a higher baseline compared with CEE states.

Another driver of public management reforms in Western Europe was associated with macro-economic problems (large government, significant budgetary deficits, and perceived lack of public-sector performance). All CEE states have small governments as measured by government expenditure as a percentage of their GDP: all countries (except for Hungary) are below the EU 27 (according the 2006 EUROSTAT data), and their social expenditure (in particular in the Baltic states) is rather low. It may seem that the rationale of NPM to downsize the government is less apparent in CEE compared to Western Europe. However, in some CEE states, performance-management systems (in Lithuania and Latvia) emerged from the impact of fiscal and economic crises, focusing the attention of policymakers on the issues of efficient public spending (Verheijen and Dobrolyubova 2007, 214). Also, in the environment of a financial crisis, it became necessary to cut public spending in some CEE states (in particular Latvia, Romania, Hungary, Ukraine and other CEE states, which asked for emergency lending from the IMF). Therefore, the financial crisis presents a window of opportunity for public-management reforms in CEE states.

\section{Conclusions and discussion}

Public-management reforms in CEE countries have achieved a mix of successes and failures. However, the reform process proved to be more difficult and slower than expected at the outset of political and economic transition as well as EU accession. It was previously concluded that public-management reforms in Russia and other former Soviet Union states are constrained by the difficulties of transferring newpublic-management ideas from the Western socio-economic context to the specific post-communist context (Peters 2008, 1).

It is worth discussing the political and governmental context of these reforms in CEE states. Although there is no common model of public-management reforms in CEE states, it is a similar reform context that was shared by these countries. This context matters because of the political nature of public-management reforms initiated by the governments in office.

It was argued in this article that the reform process in many CEE countries was dominated by short-term political interests, producing ups and downs in the government policy. This is in contrast to Western Europe, where the the zig-zag or 
action-reaction trajectories of public-management reforms were based on competing administrative doctrines (NPM followed by renewed hierarchy-type, markettype and network-type mechanisms) (Bouckaert 2009, 20).

Obviously, especially for countries that wanted to join, and ultimately joined the EU, there was a clear "to do" list, and a series of "acquis" to realise. There was economic and political pressure to prove progress, to speed up change, perhaps to take short cuts or to jump to "final" positions. Reforming the public sector sometimes was indispensable and impossible at the same time, and therefore highly problematic. Importing NPM techniques that needed to improve Weberian bureaucracies when these were not present, and simultaneously building classical checks and balances was a tough reality. Reforming in such a case sometimes was organising dysfunctions.

The political zig-zag of the reform process in CEE states could be explained by the status of their political systems and their governments. The post-communist political systems (especially in the former Soviet Union bar the Baltic states) have not been consolidated in the Western sense of democracy and market economy being "the only game in town" (Linz and Stepan 1996). It is not surprising that public administration is often abused by the ruling political and business elite as a means of obtaining rents from the population or the business community.

The new EU member states with more consolidated political systems often suffer from weak coalition governments. This is the source of government instability: it was estimated that the average office length of governments in Lithuania and Latvia was only about 16 months in the period of 1990-2008. The lack of government stability puts limits to the possibility of designing and implementing comprehensive reform strategies from the government centre (as is the case in most Western European countries).

If public-management reforms in the new $\mathrm{EU}$ member states were heavily influenced by the prospect of EU membership, it is no longer true in the post-accession period. Following their accession to the EU, the ex-ante control of the European Commission was replaced with much weaker instruments of ex-post control in the case of non-implementation or delayed implementation. It is possible that these factors reduced the willingness of the new EU member states to engage in coherent public-management reforms at the domestic level.

Overall, in the absence of external reform drivers, public-management reforms in the CEE region are likely to depend on the lengthy transformation of their political systems. However, this is conditional upon the politicians of the post-communist countries becoming more able and willing to reform the very foundations of their political systems and overcome their short-term political interests. 


\section{References}

Allen, Richard and Daniel Tommasi. 2001. Managing Public Expenditure: A Reference Book for Transition Countries. Paris: OECD.

Bouckaert, Geert. 2009. "Public Sector Reform in CEE Countries: An Introduction". In Geert Bouckaert, Juraj Nemec, Vitalis Nakrošis, Gyorgy Hajnal and Kristiina Tõnnisson (eds). Public Management Reforms in Central and Eastern Europe. Bratislava: NISPAcee.

Bouckaert, Geert, and John Halligan. 2008. Managing Performance: International Comparisons. London: Routledge.

Bouckaert, Geert, Juraj Nemec, Vitalis Nakrošis, Győrgy Hajnal and Kristiina Tõnnisson. 2009. Public Management Reforms in Central and Eastern Europe. Bratislava: NISPAcee.

Coombes, David and Tony Verheijen. 1997. Public Management Reform: Comparative Experience from East and West. Brussels: European Commission.

Drechsler, Wolfgang. 2005. “The Re-Emergence of 'Weberian' Public Administration after the Fall of New Public Management: The Central and Eastern European Perspective." Halduskultuur 6, 94-108.

Dunn, William N., Katarina Staronova and Sergei Pushkarev. 2006. Implementation: The Missing Link in the Public Administration Reform in CEE. Bratislava: NISPAcee.

Eurostat. 2009. Government finance statistics 2008. Luxembourg: Publications Office of the European Union.

Jenei, Gyorgy and Akos Szalai. 2002. "Modernizing Local Governance in a Transitional Nation: Evaluating the Hungarian Experience." Public Management Review 4 (3), 367-386.

Linz, Juan José and Alfred C. Stepan. 1996. Problems of Democratic Transition and Consolidation: Southern Europe, South America, and Post-Communist Europe. Baltimore, London: Johns Hopkins University Press.

Meyer-Sahling, Jan-Hinrik. 2009. Post-Accession Sustainability of Civil Service Reform in Central and Eastern Europe. Paris: OECD-SIGMA Publications.

Nakrošis, Vitalis. 2008. "Reforming Performance Management in Lithuania: Towards Result-Based Management". In Guy B. Peters (ed.). Mixes, Matches and Mistakes: New Public Management in Russia and the Former Soviet Republics. Budapest: Open Society Institute.

Nemec, Juraj and Colin Lawson. 2008. "Health Care Reforms in CEE: Processes, Outcomes and Selected Explanations." NISPAcee Journal of Public Administration and Policy 1 (1), 27-50. 
Obolonskij, Alexandr. 2009. Gosudarstvennaja sluzba. Moscow: Delo.

Pavel, Jan. 2009. Veřejné zakázky v ČR. Praha: Hálkova nadace.

Peters, Guy B. 2008. "Mixes, Matches and Mistakes: New Public Management in Russia and the Former Soviet Republics." In Guy B. Peters (ed.). Mixes, Matches and Mistakes: New Public Management in Russia and the Former Soviet Republics. Budapest: Open Society Institute.

Peters, Guy B. 2001. The Future of Governing. Lawrence: University Press of Kansas.

Peters, Guy B. 1996. The Future of Governing: Four Emerging Models. Lawrence: University. Press of Kansas.

Pollitt, Christopher and Geert Bouckaert. 2004. Public Management Reform: A Comparative Analysis. Oxford: Oxford University Press.

Pollitt, Christopher and Geert Bouckaert. 2000. Public Management Reform: A Comparative Analysis. Oxford: Oxford University Press.

Schick, Alan. 1998. "Why Most Developing Countries Should not Try New Zealand Reforms." World Bank Research Observer 13 (1), 123-131.

Shakarashvili, George (ed.). 2005. Decentralization in Healthcare. Budapest: OSI-LGI.

Verheijen, Tony and Yelena Dobrolyubova. 2007. "Performance Management in the Baltic States and Russia: Success against the Odds?" International Review of Administrative Sciences 73 (2), 205-215.

World Bank. 2006. Report on Strategic Planning and Policy Management in Lithuania and Latvia. October. Available at http://www.lrv.lt/strateginis/Pasaulio\%20banko\%20studija.pdf (last accessed 15.04. 2009).

World Bank. 2003. Understanding Public Sector Performance in Transition Countries: An Empirical Contribution. 30 June. Available at http://www1.worldbank.org/ publicsector/civilservice/UPSP\%20final.pdf (last accessed 15.04.2009). 